\title{
Analysis of water adsorption by wood using the Guggenheim-Anderson-de Boer equation
}

\author{
L. Bratasz • A. Kozłowska $\cdot$ R. Kozłowski
}

Received: 25 March 2011 / Published online: 25 August 2011

(C) The Author(s) 2011. This article is published with open access at Springerlink.com

\begin{abstract}
The Guggenheim-Anderson-de Boer (GAB) three-parameter sorption equation has been used to interpret the adsorption and desorption isotherms of water vapour measured for 21 important cultural heritage wood species used in the past for panel paintings and woodcarving. The equation is capable of describing the full shape of the isotherms and yields meaningful physical parameters, especially the monolayer capacity from which the water accessible specific surface area can be obtained. It is demonstrated that average sorption isotherms can be derived using the GAB equation for the sorption data available for sets of specimens and that moisture properties of various wood specimens or chemically modified wood can be more easily compared.
\end{abstract}

\section{Analyse der Wasseraufnahme von Holz mit der Guggenheim-Anderson-de Boer-Gleichung}

Zusammenfassung Anhand der dreiparametrigen Guggenheim-Anderson-de Boer-Sorptionsgleichung (GAB) wurden die Adsorptions- und Desorptionsisothermen von 21 kulturell wichtigen Holzarten bestimmt, die in früheren Zeiten für Tafelmalereien und Holzschnitzereien verwendet wurden. Mit dieser Gleichung kann die vollständige Form der Isothermen dargestellt werden. Sie liefert aussagekräftige physikalische Parameter, insbesondere die Monoschichtkapazität, aus der die für das Wasser zugängliche spezifische Oberfläche bestimmt werden kann. Es wird gezeigt, dass anhand der GAB-Gleichung aus den verfügbaren Sorptionsdaten für

Ł. Bratasz $(\bowtie) \cdot$ A. Kozłowska $\cdot$ R. Kozłowski

Jerzy Haber Institute of Catalysis and Surface Chemistry, Polish Academy of Sciences, ul. Niezapominajek 8, 30-239 Kraków, Poland

e-mail: ncbratas@cyf-kr.edu.pl verschiedene Holzartengruppen die mittleren Sorptionsisothermen hergeleitet werden können und dass die Feuchteeigenschaften verschiedener Holzarten oder von chemisch modifiziertem Holz einfacher verglichen werden können.

\section{Introduction}

Wood is a hygroscopic material, gaining moisture when the relative humidity $(\mathrm{RH})$ is high, or losing moisture when the surrounding air is dry. The moisture content in wood exposed to a given temperature and RH eventually attains a constant level termed the equilibrium moisture content (EMC). As the amount of water sorbed by wood markedly affects a range of its properties, the relationships between the RH and EMC at constant temperatures (water sorption isotherms) have received much attention in wood science. There has been general agreement that several types of wood-water interactions prevail at different levels of RH.

The most comprehensive picture of these interactions is obtained when desorption is carried out from the fully saturated state where all cell cavities are filled with water introduced under pressure. By use of the pressure membrane procedure, EMC values for high nominal RH ranges between $96-100 \%$ are obtained, followed by standard measurements of the mass loss of wood exposed to decreasing water vapour pressures (Almeida and Hernández 2006; Hernández and Pontin 2006). Such a desorption curve is termed the boundary desorption curve and it plots the maximum EMC expected for each RH condition on desorption (Defo et al. 1999). Two types of water are present in wood at saturation: 'bound water' adsorbed on the surface of structures building cell walls and 'liquid or lumen water' present in the capillaries of the wood microstructure (Almeida et 
al. 2007). When RH decreases, the capillaries are gradually emptied until Fiber Saturation Point (FSP) is reacheddefined as EMC at which the cell walls are saturated with bound water, with no liquid water in the lumens. However, it was demonstrated that a loss of bound water can occur at EMC well above FSP, with liquid water entrapped in the smallest capillaries and channels in the wood. The loss of liquid water is usually complete at RH levels below $60 \%$.

This study is part of a broader work on the moistureinduced response of wooden objects of cultural heritage, which will help to better understand RH ranges that are safe for their preservation. Therefore, the work focuses on the range between $0 \%$ and $90 \% \mathrm{RH}$, which is of interest for the preservation of wooden objects indoors. For this range, the relationships between the amount of the bound water in the cell walls and RH is described by a sigmoid shape of the type II isotherm in the IUPAC 1985 classification (Sing et al. 1985). It indicates the monolayer-multilayer physisorption where an adsorbed surface layer progressively thickens as the vapour pressure is increased up to saturation pressure. At high RH values, the monolayer-multilayer adsorption path can be accompanied by a more rapid increase in sorbed water due to the processes of capillary condensation in the porous structure or opening up more internal surfaces for adsorption in terms of the hydrogen bonds between the cellulose-cellulose molecules being broken and replaced by hydrogen bonds between cellulose and water molecules (Chauhan and Aggarwal 2004).

The Guggenheim-Anderson-de Boer (GAB) three-parameter sorption equation was used to interpret the physisorption of water on wood as it is capable of describing the full shape of type II isotherm and yields meaningful physical parameters as monolayer capacity and energy constant related to the net molar heat of adsorption (Timmermann 2003; Hartley 2000). Furthermore, it was shown that the GAB equation is equivalent to the Hailwood and Horrobin equation widely used to describe the moisture sorption by wood (Hailwood and Horrobin 1946). The parameters obtained from the sorption equations have so far not been fully interpreted in terms of energy constants and specific surface areas on which an adsorbed layer is formed; the approach has been extremely popular for adsorbents, catalysts and other fine or porous materials. In this paper, the potential of GAB analysis is explored using experimental sorption data of a number of wood species. It is demonstrated how the analysis helps to compare moisture properties of various wood specimens or chemically modified woods with reliability and precision. Average GAB constants are obtained by fitting water vapour sorption data for many wood types, and such information can be very useful in modelling the moisture-induced response of wood in general as a material.

\section{Materials and methods}

The water vapour sorption data of 21 wood species were analysed in this study: lime (Tilia sp.), pine (Pinus sylvestris L.), fir (Abies alba Mill.), larch (Larix sp.), spruce (Picea abies L.), oak (Quercus sp.), ash (Fraxinus excelsior L.), poplar (Populus sp.), sycamore maple (Acer pseudoplatanus L.), willow (Salix sp.), beech (Fagus sylvatica L.), birch (Betula verrucosa Ehrn.), elm (Ulmus sp.), alder (Alnus sp.), walnut (Juglans sp.), sour cherry (Prunus cerasus sp.), cherry (Cerasus sp.), apple (Malus sp.), rosewood (Dalbergia sp.), mahogany (Swietenia sp.), Japanese cypress (Chamaecyparis obtusa). The selection was based on the list of types of wood used in the past for panel paintings and woodcarving published by Grosser and Geier (1975) for softwoods, and by Grosser and Grässle (1976) for hardwoods. The specimens were obtained from defectfree wooden boards seasoned for at least three years at room conditions.

Water vapour adsorption and desorption isotherms were determined at $24^{\circ} \mathrm{C}$ and for a full range of water vapour relative pressures. The measurements were done gravimetrically with the use of a vacuum microbalance from CI Electronics Ltd. Typically a $0.05 \mathrm{~g}$ piece of wood was weighed and outgassed prior to a measurement under a vacuum of a residual pressure of less than $0.1 \mathrm{~Pa}$. The aim was to move the air out of the wood and to eliminate most of the species physisorbed during the storage of the sample, especially adsorbed water. A vacuum was maintained until constant weight was obtained, then subsequent portions of water vapour were introduced and the respective mass increased due to the sorption, and the equilibrium pressures were recorded. Samples were considered to have reached 'equilibrium' when the weight changes were less than $0.05 \%$ in 40 minutes. The EMC values were calculated on the basis of the initial weight of the outgassed sample. The process was fully automated and rapid; the measuring of 10 adsorption and 10 desorption points took on average 15 hours. To each adsorption and desorption point an exponential growth curve was fitted to find the true EMC value.

In order to verify if outgassing under vacuum conditions introduces any modification to the subsequent sorption process, traditional sorption tests were carried out by exposing selected specimens above saturated solutions of various salts in containers maintained at $24^{\circ} \mathrm{C}$. The specimens were dried in a microclimatic chamber at $102^{\circ} \mathrm{C}$ before the adsorption tests for one month. Prior to the desorption tests the dried samples were exposed above distilled water. Five wood samples were measured for each experimental point. The comparison of the isotherms measured with the use of the two methods shows an excellent agreement, as illustrated in Fig. 1 for lime wood. 


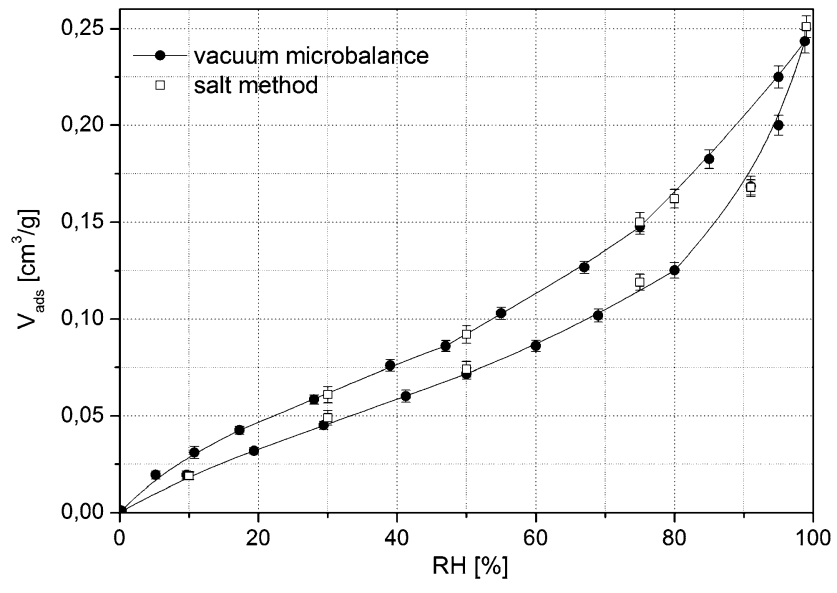

Fig. 1 Adsorption and desorption isotherms of water vapour for lime wood at $20^{\circ} \mathrm{C}$. Filled circles and open squares correspond to two experimental techniques used: gravimetric measurements in a vacuum microbalance or conditioning the specimens over saturated salt solutions, respectively

Abb. 1 Wasserdampfadsorptions- und Desorptionsisothermen für Lindenholz bei $20^{\circ} \mathrm{C}$. Ausgefüllte Kreise und leere Quadrate bezeichnen die zwei verwendeten Versuchsverfahren: gravimetrische Messungen in einer Vakuum-Mikrowaage bzw. Konditionierung der Prüfkörper über gesättigten Salzlösungen

\section{Analysis of sorption isotherms}

The three-parameter Guggenheim-Anderson-de Boer sorption equation (Timmermann 2003) is used to interpret the sorption data for wood by expressing the volume of adsorbed water as a function of relative humidity:

$$
\begin{aligned}
& V_{a d s}(R H, T=\text { const. }) \\
& \quad=\frac{V_{m} * c * k * R H / 100}{(1-k * R H / 100)(1+(c-1) k * R H / 100)}
\end{aligned}
$$

where $V_{a d s}$ is the volume of adsorbed water in $\mathrm{cm}^{3}$ per gram of dry wood, $\mathrm{RH}$-relative humidity in percent, $V_{m}$ - the monolayer capacity in the same units as $V_{a d s}, c$-an energy constant related to the difference of free enthalpy (standard chemical potential) of water molecules in the upper sorption layers and in the monolayer, and $k$-the third parameter, related in turn to the difference of free enthalpy of water molecules in the pure liquid and the upper sorption layers.

The specific surface area $\mathrm{s}_{G A B}$ is obtained from the monolayer capacity $V_{m}$ by the application of a relation:

$s_{G A B}=V_{m} * \rho * L * \sigma / M$

where $M$ is the molar mass of water, $\rho$ is water density, $L$ is the Avogadro number and $\sigma$ is the average area occupied by one water molecule in the complete monolayer $-0.114 \mathrm{~nm}^{2}$ was used in this work.

In the present study, the GAB constants were determined by a least-squares regression of the sorption data in the range $5 \%<R H<85 \%$, separately for the adsorption and desorption branches. By way of example, the GAB sorption equation was capable of describing the isotherm's shape for the

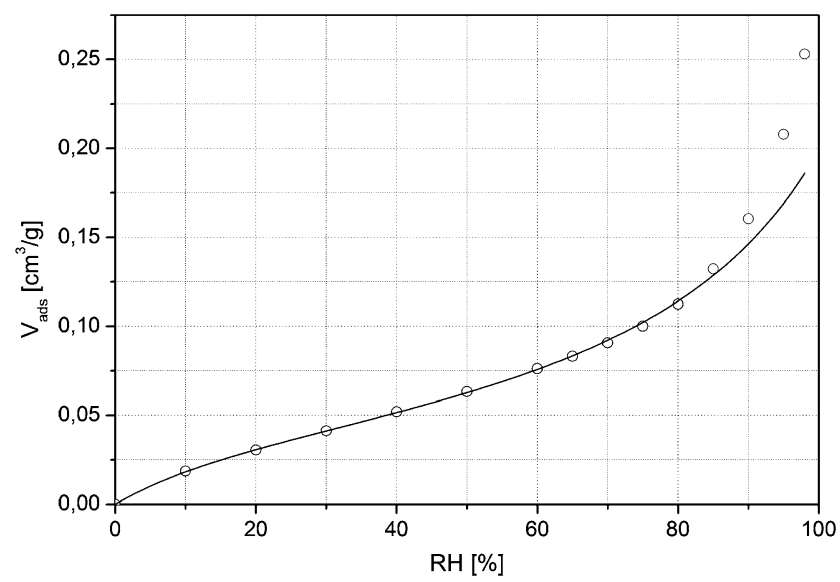

Fig. 2 The experimental data for water vapour sorption by lime wood are compared with the curve calculated from the least-square regression of data to the GAB isotherm

Abb. 2 Vergleich der Versuchsdaten der Wasserdampfsorption von Lindenholz mit der über eine Regressionsanalyse bestimmten GAB-Isotherme

lime wood within the range $8 \%<R H<85 \%$ as illustrated in Fig. 2

The sets of values of GAB constants obtained from the regression of the experimental data for all 21 wood species analysed are given in Table 1 separately for the adsorption and desorption branches. It should be stressed at this point that the adsorption branch only yields meaningful physical parameters - the monolayer capacity and the energy constant - as a distinctive and reproducible hysteresis loop appears between the adsorption and desorption branches, i.e., higher moisture content during desorption when compared to that during adsorption at any given $\mathrm{RH}$ value. This phenomenon is associated with the swelling of a non-rigid wood structure in the course of adsorption, so that the effect is in fact a manifestation of elastic hysteresis (Sing et al. 1985). A set of GAB constants was also obtained for the sorption data of the microcellulose MCC $\left(V_{m}=0.042\right.$, $c=9.2, k=0.76)$. MCC is a pure cellulose powder which has been adopted as a certified reference material in the procedure for the determination of water sorption isotherms, especially of foods (Jowitt and Wagstaffe 1989).

Further to the analysis of sorption data for the individual wood species, average GAB constants with corresponding uncertainties were obtained by fitting the entire sets of adsorption and desorption data available for all 21 wood species analysed to the GAB equation. A set of GAB constants with corresponding uncertainties was also obtained for a general relationship between $V_{a d s}$, RH and temperature proposed by Simpson and TenWolde (1999). The two general relationships are shown in Fig. 3 and the respective GAB constants are given in Table 1 .

Much attention is usually paid in the analysis of the adsorption data to monolayer capacity values, as they 
Table 1 GAB constants and specific surface areas obtained from the regression of the experimental data for water vapour sorption by 21 wood species

Tab. 1 GAB-Konstanten und spezifische Oberfläche von 21 Holzarten, ermittelt mittels Regressionsanalyse aus den Versuchsdaten der Wasserdampfsorption

\begin{tabular}{|c|c|c|c|c|c|c|c|}
\hline \multirow[t]{2}{*}{ Wood species } & \multicolumn{4}{|c|}{ Adsorption branch } & \multicolumn{3}{|c|}{ Desorption branch } \\
\hline & $\begin{array}{l}V_{m} \\
{\left[\mathrm{~cm}^{3} / \mathrm{g}\right]}\end{array}$ & $c$ & $k$ & $\begin{array}{l}s_{G A B} \\
{\left[\mathrm{~m}^{2} / \mathrm{g}\right]}\end{array}$ & $\begin{array}{l}V_{m} \\
{\left[\mathrm{~cm}^{3} / \mathrm{g}\right]}\end{array}$ & $c$ & $k$ \\
\hline Sycamore & 0.045 & 12 & 0.79 & 172 & 0.069 & 10.74 & 0.66 \\
\hline Japanese cypress & 0.050 & 12 & 0.76 & 189 & 0.084 & 9.07 & 0.62 \\
\hline Mahogany & 0.050 & 14 & 0.81 & 190 & 0.112 & 7.86 & 0.59 \\
\hline Lime & 0.050 & 6.3 & 0.75 & 190 & 0.079 & 7.42 & 0.06 \\
\hline Elm & 0.053 & 15 & 0.81 & 201 & 0.091 & 7.03 & 0.66 \\
\hline Fir & 0.055 & 14 & 0.79 & 210 & 0.087 & 9.86 & 0.64 \\
\hline Pine & 0.057 & 9.6 & 0.77 & 218 & 0.093 & 12.47 & 0.64 \\
\hline Birch & 0.058 & 8.9 & 0.78 & 219 & 0.109 & 6.86 & 0.54 \\
\hline Beech & 0.058 & 9.4 & 0.79 & 220 & 0.077 & 9.52 & 0.71 \\
\hline Oak & 0.058 & 7.4 & 0.77 & 220 & 0.093 & 8.24 & 0.60 \\
\hline Walnut & 0.059 & 7.3 & 0.69 & 224 & 0.104 & 4.36 & 0.56 \\
\hline Cherry & 0.059 & 9.9 & 0.72 & 225 & 0.086 & 7.01 & 0.66 \\
\hline Sour cherry & 0.059 & 10 & 0.77 & 226 & 0.082 & 9.83 & 0.72 \\
\hline Poplar & 0.060 & 9.6 & 0.73 & 227 & 0.081 & 7.88 & 0.68 \\
\hline Alder & 0.0597 & 6.6 & 0.71 & 227 & 0.769 & 9.56 & 0.634 \\
\hline Rosewood & 0.061 & 9.3 & 0.66 & 233 & 0.079 & 9.18 & 0.64 \\
\hline Willow & 0.066 & 8.0 & 0.73 & 251 & 0.091 & 7.03 & 0.66 \\
\hline Ash & 0.066 & 8.9 & 0.68 & 253 & 0.091 & 8.32 & 0.65 \\
\hline Spruce & 0.068 & 10 & 0.74 & 260 & 0.080 & 12.49 & 0.70 \\
\hline Apple tree & 0.068 & 7.7 & 0.73 & 260 & 0.015 & 5.15 & 0.64 \\
\hline Larch & 0.071 & 9.9 & 0.74 & 269 & 0.073 & 9.05 & 0.72 \\
\hline 'Average' wood & 0.059 & 8.8 & 0.74 & 226 & 0.079 & 9.24 & 0.69 \\
\hline Standard deviation & 0.005 & 1.6 & 0.04 & 19 & 0.004 & 1.60 & 0.02 \\
\hline $\begin{array}{l}\text { 'General' relationship } \\
\text { (Simpson and } \\
\text { TenWolde 1999) }\end{array}$ & 0.0665 & 7.45 & 0.77 & 253 & & & \\
\hline Standard deviation & 0.0009 & 0.4 & 0.003 & 3 & & & \\
\hline
\end{tabular}

determine the internal specific surface area of the sorbent. The adsorption isotherms for the woods of the lowest and the highest monolayer capacity values (sycamore maple- $0.0457 \mathrm{~cm}^{3} / \mathrm{g}, s_{G A B}=172 \mathrm{~m}^{2} / \mathrm{g}$ and larch$0.0707 \mathrm{~cm}^{3} / \mathrm{g}, s_{G A B}=269 \mathrm{~m}^{2} / \mathrm{g}$ ) are presented in Fig. 4 together with the average isotherm. In turn, the energy constants $\mathrm{c}$ and $\mathrm{k}$ determine the details of the sigmoidal shape of the isotherms (Timmermann 2003). So the constant c determines the more or less pronounced 'knee' at the RH range of around $30 \%$ and the constant $\mathrm{k}$ determines the curvature of the isotherm above the flat mid-region at higher RH: higher values of $k$ establish a more pronounced upswing. The effect is illustrated in Fig. 5 by comparing the sorption data of elm and walnut which have one of the highest and lowest $c$ and $k$ values in the group of specimens analysed.

\section{Comparing moisture properties of various wood specimens}

GAB analysis can be used to compare moisture properties of various wood specimens or chemically modified woods with reliability and precision. By way of example, GAB constants were obtained from the regression of the several individual experimental water vapour sorption data for various pine woods; the average GAB constants were also obtained for all the sorption data available (Table 2). A close agreement of the obtained constants point to a uniform moisture behaviour of all the woods analysed.

In contrast, a considerable evolution of GAB constants is observed when analysing the water vapour sorption data for the Corsican pine modified with linear chain carboxylic acid anhydrides (Papadopoulos and Hill 2003). By way of 


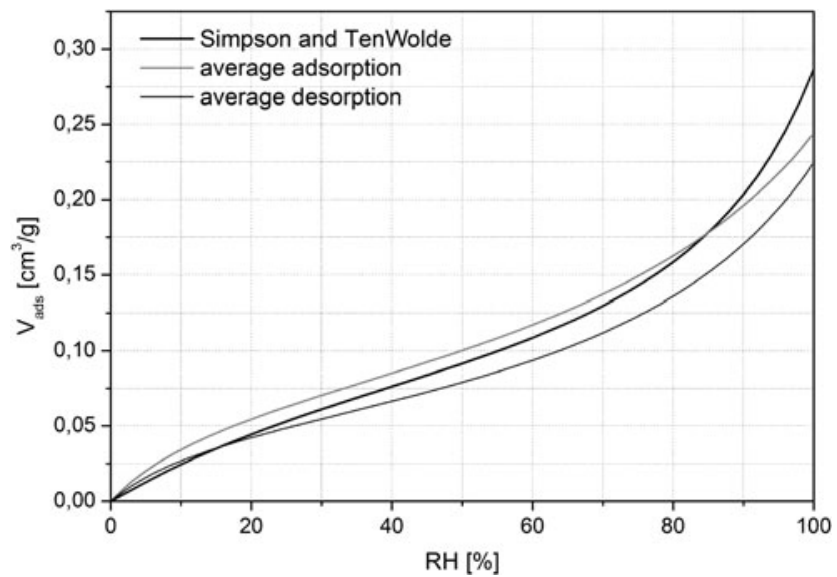

Fig. 3 Average adsorption and desorption isotherms of water vapour calculated from the GAB equation using constants obtained by fitting the entire sets of adsorption and desorption data available for 21 wood species analysed. A 'general' adsorption curve by Simpson and TenWolde (1999) is plotted for comparison

Abb. 3 Mittlere Wasserdampfadsorptions- und Desorptionsisothermen berechnet mit der GAB-Gleichung mittels Konstanten, die unter Verwendung aller verfügbarer Adsorptions- und Desorptionsdaten der 21 untersuchten Holzarten ermittelt wurden. Zum Vergleich ist eine ,allgemeine“ Adsorptionskurve von Simpson and TenWolde (1999) angegeben

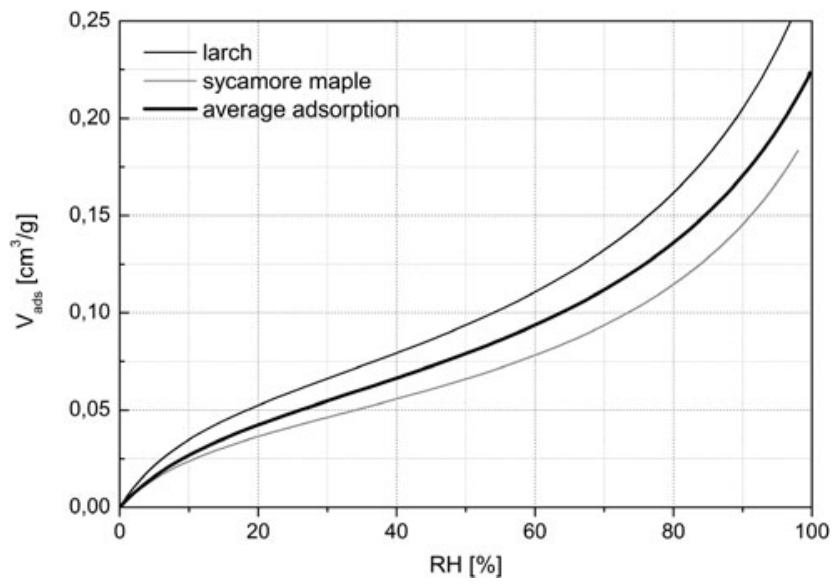

Fig. 4 Adsorption curves for woods of the highest (larch) and lowest (sycamore maple) monolayer capacity compared with the average adsorption

Abb. 4 Vergleich der Adsorptionskurven für Holzarten mit der höchsten (Lärche) und der niedrigsten (Bergahorn) Monoschichtkapazität mit der mittleren Adsorptionskurve

example, the data for specimens modified with acetic anhydride at an increasing level of reaction are analysed here in detail (Table 3 and Fig. 6). The level of reaction with the modifying agent is expressed in terms of a weight percent gain (WPG) by a specimen. As expected, the water accessible surface area decreases as the WPG increases, indicating a proportion of sites that have been occupied by the acetic groups and hence made unavailable for water sorption. A systematic change in the constants $\mathrm{c}$ and $\mathrm{k}$ is also observed.

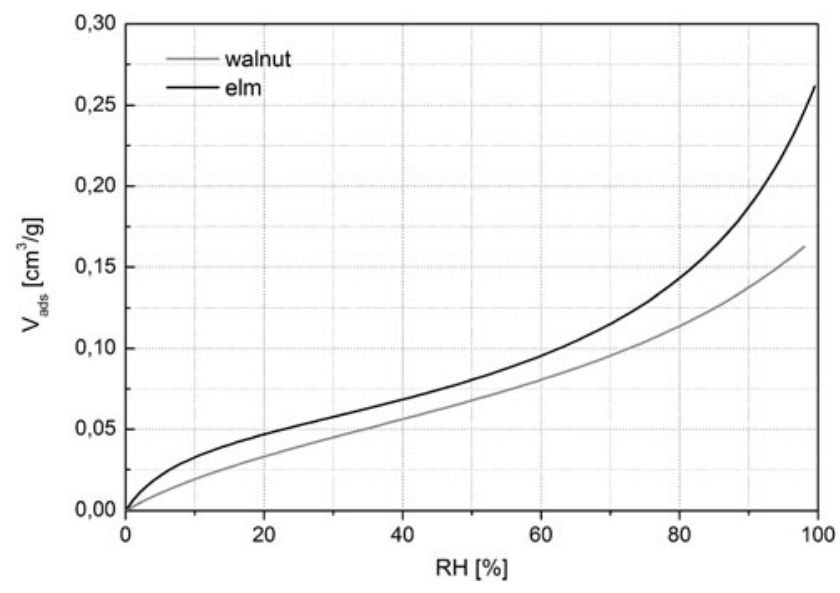

Fig. 5 Adsorption curves for woods of high (elm) and low (walnut) $c$ and $k$ constants

Abb. 5 Adsorptionskurven für Holzarten mit hohen (Ulme) und niedrigen (Walnuss) $c$ und $k$ Konstanten

Table 2 GAB constants and specific surface areas obtained from the regression of the experimental data for water vapour sorption by four pine woods

Tab. 2 GAB-Konstanten und spezifische Oberfläche von 4 Kiefernarten, ermittelt mittels Regressionsanalyse aus den Versuchsdaten der Wasserdampfsorption

\begin{tabular}{lllll}
\hline Pine woods & $\begin{array}{l}V_{m} \\
{\left[\mathrm{~cm}^{3} / \mathrm{g}\right]}\end{array}$ & $c$ & $k$ & $\begin{array}{l}s_{G A B} \\
{\left[\mathrm{~m}^{2} / \mathrm{g}\right]}\end{array}$ \\
\hline $\begin{array}{l}\text { Corsican pine (Pinus nigra) } \\
\text { (Papadopoulos and Hill 2003) }\end{array}$ & 0.062 & 6.4 & 0.75 & 236 \\
$\begin{array}{l}\text { Lodgepole pine (Pinus contorta) } \\
\text { (Fan et al. 1999) }\end{array}$ & 0.061 & 6.42 & 0.77 & 234 \\
$\begin{array}{l}\text { Lodgepole pine (Pinus contorta) } \\
\text { (Koumoutsakos and Avramidis }\end{array}$ & 0.061 & 8.2 & 0.77 & 232 \\
$\begin{array}{l}\text { 1999) } \\
\begin{array}{l}\text { Scots pine (Pinus sylvestris L.) } \\
\text { (this work) }\end{array}\end{array}$ & 0.057 & 9.6 & 0.77 & 218 \\
'Average' pine & 0.0617 & 7.7 & 0.75 & 235 \\
\hline
\end{tabular}

Both constants tend to decrease as the reaction progresses indicating a gradual reduction of the effective chemical potential of the adsorbing surface.

The adsorption isotherms for the modified wood are easier to interpret if the RH values on the ordinate axis are replaced by those of $t$, the statistical thickness of the water layer adsorbed on the unmodified wood serving as a standard:

$t(R H)=V_{a d s} / s_{G A B}$

The same $V_{a d s}-R H$ adsorption isotherms as in Fig. 6 are shown in Fig. 7 as $V_{a d s}-t$ plots. Since the volume adsorbed is a product of surface area and water layer thickness, a straight line graph is obtained as long as the water layer can grow freely on the entire surface of the sample and its slope represents a water vapour accessible surface area. As 
Table 3 GAB constants obtained from the regression of the experimental data for water vapour sorption for pine specimens modified with acetic anhydride at an increasing level of reaction expressed in terms of weight percent gain, and specific surface areas calculated from the $V_{m}$ constant or a $V-t$ plot

Tab. 3 Mittels Regressionsanalyse aus den Versuchsdaten ermittelte GAB-Konstanten von mit Essigsäureanhydrid behandelten Kiefernprüfkörpern in Abhängigkeit des Reaktionsgrades, angegeben als prozentuale Gewichtszunahme, sowie spezifische Oberflächen, berechnet aus der $V_{m}$ Konstante oder dem $V-t$ Diagram

\begin{tabular}{llllll}
\hline $\begin{array}{l}\text { Weight percent } \\
\text { gain [\%] }\end{array}$ & $\begin{array}{l}V_{m} \\
{\left[\mathrm{~cm}^{3} / \mathrm{g}\right]}\end{array}$ & $c$ & $k$ & $\begin{array}{l}s_{G A B} \\
{\left[\mathrm{~m}^{2} / \mathrm{g}\right]}\end{array}$ & $\begin{array}{l}s_{V-t} \\
{\left[\mathrm{~m}^{2} / \mathrm{g}\right]}\end{array}$ \\
\hline 5.2 & 0.053 & 6.2 & 0.74 & 202 & 196 \\
11.4 & 0.047 & 5.9 & 0.75 & 179 & 178 \\
15.8 & 0.038 & 6.3 & 0.74 & 145 & 142 \\
19.6 & 0.036 & 5.1 & 0.72 & 137 & 129 \\
22.5 & 0.035 & 3.9 & 0.70 & 133 & 121 \\
\hline
\end{tabular}

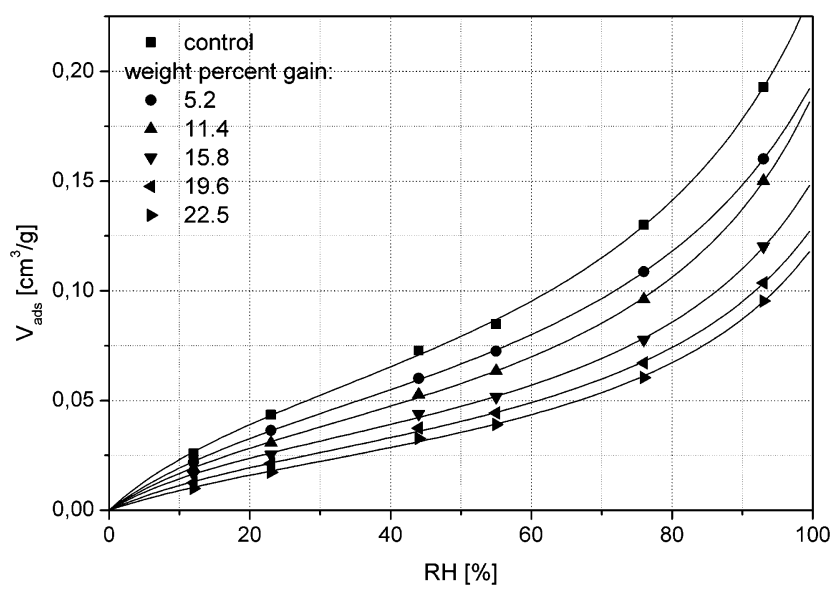

Fig. 6 Adsorption data for pine specimens modified with acetic anhydride at an increasing level of reaction (data by Papadopoulos and Hill 2003)

Abb. 6 Adsorptionskurven von mit Essigsäureanhydrid behandelten Kiefernprüfkörpern in Abhängigkeit des Reaktionsgrades (Daten von Papadopoulos und Hill 2003)

expected, decreasing slopes are observed with decreasing WPG, however, the specific surface areas calculated $-s_{v-t}$, listed in Table 3, differ to some extent from $\mathrm{s}_{G A B}$ obtained from the GAB analysis of the sorption data. The difference points to an increasing change in the shape of the sorption isotherms of the modified wood when compared to the unmodified wood. The change is also reflected in the downward displacements of the $V_{a d s}-t$ plots observed due to the reduced effective chemical potential of the modified wood.

\section{Conclusion}

The analysis of the water sorption isotherms for wood using the GAB equation has provided a good tool for the detailed

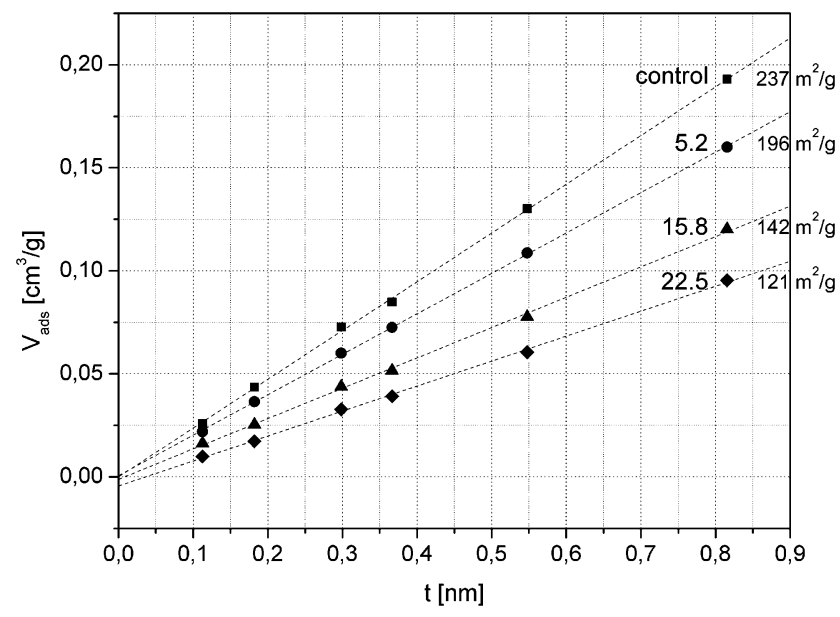

Fig. $7 V_{a d s}-t$ plots for pine specimens modified with acetic anhydride at an increasing level of reaction (data by Papadopoulos and Hill 2003) Abb. $7 V_{a d s}-t$-Diagram von mit Essigsäureanhydrid behandelten Kiefernprüfkörpern in Abhängigkeit des Reaktionsgrades (Daten von Papadopoulos und Hill 2003)

comparison of moisture properties of various wood specimens or chemically modified wood. In particular, the GAB monolayer capacity parameter has allowed precise assessment of the water accessible specific surface area of wood. It was also demonstrated that the 'average' or 'general' sorption isotherm can be derived from the sorption data available for various sets of specimens. Such generalised information can be particularly useful in modelling responses of wood as a material to changes in climate conditions in its environment.

Acknowledgements This research was supported by grant PL0086 from Iceland, Liechtenstein and Norway through the European Economy Area Financial Mechanism, a grant from the Polish Ministry of Science and Higher Education supporting activities of COST Action IE0601 "Wood science for conservation of cultural heritage" as well as a grant from the Polish Ministry of Science and Higher Education No N N105 278536.

Open Access This article is distributed under the terms of the Creative Commons Attribution Noncommercial License which permits any noncommercial use, distribution, and reproduction in any medium, provided the original author(s) and source are credited.

\section{References}

Almeida G, Hernández RE (2006) Changes in physical properties of yellow birch below and above the fiber saturation point. Wood Fiber Sci 38:74-83

Almeida G, Gagné S, Hernández RE (2007) A NMR study of water distribution in hardwoods at several equilibrium moisture contents. Wood Sci Technol 41:293-307

Chauhan SS, Aggarwal P (2004) Effect of moisture sorption state on transverse dimensional changes in wood. Holz Roh- Werkst 62:50-55

Defo M, Fortin Y, Cloutier A (1999) Moisture content-water potential relationship of sugar maple and white spruce wood from green to dry conditions. Wood Fiber Sci 31:62-70 
Fan K, Hatzikiriakos SG, Avramidis S (1999) Determination of the surface fractal dimension from sorption isotherms of five softwoods. Wood Sci Technol 33:139-149

Grosser D, Geier E (1975) Die in der Tafelmalerei und Bildschnitzerei verwendeten Holzarten und ihre Bestimmung nach mikroskopischen Merkmalen. Teil 1. Nadelhölzer. Maltechnik/Restauro: $127-148$

Grosser D, Grässle E (1976) Die in der Tafelmalerei und Bildschnitzerei verwendeten Holzarten und ihre Bestimmung nach mikroskopischenMerkmalen. Teil 2. Die Europäischen Laubhölzer. Maltechnik/Restauro: 40-54

Hartley ID (2000) Application of the Guggenheim-Anderson-de Boer sorption isotherm model to Klinki pine (Araucaria klinkii Lauterb.). Holzforschung 54:661-663

Hailwood AJ, Horrobin S (1946) Absorption of water by polymers, Analysis in terms of a simple model. Trans Faraday Soc 42B:84102

Hernández RE, Pontin M (2006) Shrinkage of three tropical hardwoods below and above the fiber saturation point. Wood Fiber Sci 38:474-483
Jowitt R, Wagstaffe PJ (1989) The certification of the water content of microcrystalline cellulose (MCC) at 10 water activities. BCR information reference materials. Report EUR 12429, Office for Official Publications of the European Communities, Luxembourg Koumoutsakos A, Avramidis S (1999) Enthalpy-entropy compensation in water sorption by various wood species. Holz Roh- Werkst 57:379-382

Papadopoulos AN, Hill CAS (2003) The sorption of water vapour by anhydride modified softwood. Wood Sci Technol 37:221-231

Simpson W, TenWolde A (1999) Physical properties and moisture relations of wood. Wood handbook, wood as an engineering material. Forest Products Society, Madison

Sing KSW, Everett DH, Haul RAW, Moscou L, Pierotti RA, Rouquerol J, Siemieniewska T (1985) Reporting physisorption data for gas solid systems with special reference to the determination of surface area and porosity. Pure Appl Chem 57:603-619

Timmermann EO (2003) Multilayer sorption parameters: BET or GAB values? Colloids Surf, A, Physicochem Eng Asp 220:235-260 